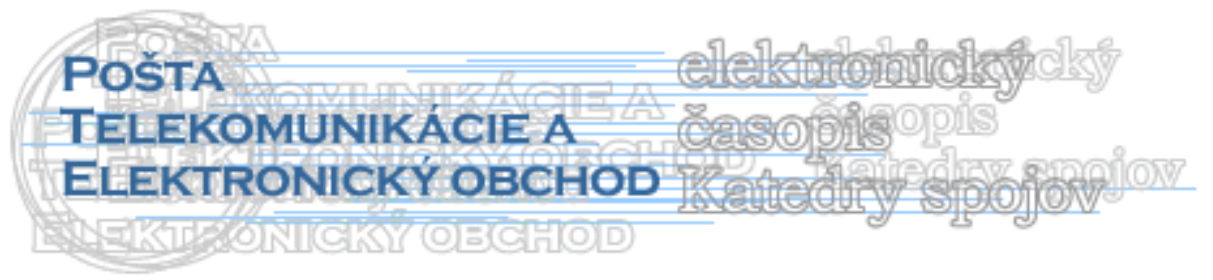

\title{
ÚVEROVÉ MOŽNOSTI MALÝCH A STREDNÝCH PODNIKOV
}

\section{Pavel Kaštánek*}

Dôležitost' malých a stredných podnikov ako neoddelitel'nej súčasti hospodárstva a hlavného zdroja súčasnej i budúcej zamestnanosti si uvedomujú všetky vyspelé ekonomiky sveta.. Malým a stredným podnikom sa na Slovensku pripisuje klúčový význam ako zdroja nápadov, nových produktov a predovšetkým pracovných príležitostí. Je zrejmý trend klesajúcej zamestnanosti vo vel'kých podnikoch a rastúca zamestnanost' v malých a stredných podnikoch. Mikropodniky majú mnohé špecifické problémy a pravdepodobne sú tou skupinou malých a stredných podnikov, ktorá trpí najviac rôznymi administratívnymi bremenami a predpismi.

Európska rada v marci 2000 v Lisabone stanovila ciel' urobit' z Európy najkonkurenčnejšiu a najdynamickejšiu ekonomiku sveta zloženú na poznatkoch. Tento ciel' zdôrazňuje dôležitost' vytvorenia prostredia vhodného pre malé a stredné podniky. Znamená to potrebu podnietenia podnikatel'ských iniciatív, pritiahnutie dostatočného rizikového kapitálu na začatie podnikania a udržanie silnej európskej základne, zatial' čo bude vytvárat' podmienky na uplatnenie inovácií. Konkurencieschopnost', inovácia a podpora podnikatel'skej kultúry sú základnými predpokladmi pre zabezpečenie rastu hospodárstva a v prvom rade malých a stredných podnikov nielen v najvyspelejších krajinách Európskej únie, ale aj na Slovensku.

Podpora malého a stredného podnikania v Slovenskej republike je oblast', ktorá si vyžaduje sústavnú pozornost'. Mení sa počet, kvalita a zameranie iniciatív a organizácií na podporu malého a stredného podnikania na medzinárodnej, národnej i miestnej úrovni. Tieto iniciatívy majú rôznu formu - sú to poradenské centrá, vzdelávacie zariadenia atd'. Slovenské malé a stredné podniky majú možnost' využitia podpory z množstva programov poskytujúcich priamu i nepriamu finančnú pomoc. Iniciátormi sú vláda Slovenskej republiky, nevládne inštitúcie a rôzne medzinárodné organizácie. Napriek tomu prax neustále ukazuje, že podnikatelia majú o týchto formách podpory podnikania nedostatok informácií.

$\mathrm{Na}$ Slovensku sa stále stretávame s bariérami neinformovanosti či nedostatočnej podpory sektoru malých a stredných podnikov.

Dostupnost' kapitálu pre malých a stredných podnikatel'ov je stále nepriaznivá. Banky nie sú ochotné poskytovat' úvery malým a predovšetkým začínajúcim firmám. Dôvodom sú hlavne požadované vysoké záruky. Napriek tomu pozitívom je existencia vybudovaného inštitucionálneho systému finančnej podpory malého a stredného podnikania na Slovensku, ktorý dáva predpoklady na zavádzanie nových produktov a zdrojové doplnananie vybraných programov podpory a rozvoja malých a stredných podnikov.

Dobré fungovanie subjektov podnikatel'skej sféry si vyžaduje aj podporu zo strany štátu v podobe určitej finančnej „injekcie“, ktorá je zabezpečená zo štátneho rozpočtu,

\footnotetext{
* Ing. Pavel Kaštánek, FPEDAS, ŽU v Žiline, Univerzitná 1, 01026 Žilina, Slovensko, tel.: +421 415133122 , fax: +421415655615

e-mail: pavel.kastanek@fpedas.uniza.sk
} 
rozpočtu územných celkov, prípadne fondov vrátane zahraničnej pomoci. Ciel’om finančnej podpory by mala byt' predovšetkým pomoc pre malé a stredné podniky pri prekonaní počiatočných bariér nedostatku finančných zdrojov. Samozrejme okrem podpory spínajú aj funkcie z hl'adiska makroekonomického, čo znamená, že hlavnou úlohou týchto programov je aj podpora zamestnanosti, podpora výroby a podpora služieb.

Podpora podnikatel'skej činnosti a osobitne malých a stredných podnikov je výsadou tejto formy podnikania vo väčšine vyspelých krajín. Na podporu malých a stredných podnikov vláda vytvorila niekol'ko podporných programov. Inštitúciami, ktoré významne koordinujú pomoc a podporu pre malé a stredné podniky je predovšetkým Národná agentúra pre rozvoj malého a stredného podnikania spolu s d'alšími inštitúciami ako sú Slovenská záručná a rozvojová banka, a.s. a Eximbanka SR. Najvýznamnejším poskytovatel'om pomoci je Ministerstvo hospodárstva SR.

Ciel'om Národnej agentúry pre rozvoj malého a stredného podnikania je podpora a rozvoj malého a stredného podnikania v Slovenskej republike so zretel'om na štátnu štrukturálnu, priemyselnú, technickú, regionálnu a sociálnu politiku. Základné programy, ktoré poskytuje sú finančné podporné programy (Schéma podpory poradenstva a vzdelávania pre malých a stredných podnikatel'ov, Schéma podporu nákupu inovatívnych technológií a budovania systémov manažérstva kvality, Program Európske informačné centrum, WWW stránka pre malých a stredných podnikatel'ov).

Medzi najvýznamnejšie aktivity Ministerstva hospodárstva SR v oblasti malé a stredného podnikania patria štátne podporné programy, ktoré sa realizujú prostredníctvom Národnej agentúry pre rozvoj malého stredného podnikania, Slovenskej záručnej a rozvojovej banky, a.s., Slovenskej energetickej agentúry a Slovenskej agentúry pre podporu úspor energie a využitia obnovitel'ných energetický zdrojov, Schéma na podporu začínajúcich podnikatel'ov ŠTART, Schéma podpory zavádzania elektronického podpisu a Štátna pomoc na rozvoj regiónov vo forme investičných stimulov.

Pomoc Európskej únie je zameraná hlavne na štrukturálne fondy, ktorými sú Európsky fond regionálneho rozvoja, Európsky sociálny fond, Európsky pol'nohospodársky usmerňovací a garančný fond, usmerňovacia sekcia a Finančný nástroj na usmerňovanie rybolovu.

V záujme podpory malého a stredného podnikania na Slovensku, ktoré je definované ako jedna z priorít hospodárstva, je potrebné pokračovat' $v$ realizácii finančných podporných programov s orientáciou na ich reálnu dostupnost' pre sektor malého a stredného podnikania. Existujúci systém podpory treba doplnit' najmä implementovaním nových foriem financovania malých a stredných podnikatel'ov. Súčasne je potrebné sledovat' vývoj na finančnom trhu a operatívne prispôsobovat' podmienky jednotlivých finančných podporných programov tak, aby napín̆ali svoje poslanie a v maximálnej miere ul'ahčili pre podnikatel'ov prístup ku kapitálu.

Malé podniky sú spravidla podkapitalizované. Vysoké riziko (neexistencia úverovej histórie, relatívne vysoká miera zadíženia, obmedzená schopnost' ručenia), ale aj malý objem pôžičky sú dôvodom obmedzeného prístupu k zdrojom a na strane druhej aj dôvodom tvrdých podmienok, v ktorých malé a stredné podniky existujú.

Malé a stredné podniky majú teda pomerne vel'ké problémy pri tvorbe, resp. pri získavaní kapitálu. S klesajúcou vel'kost'ou podniku ubúda jeho kapitálová vybavenost', a to najmä podiel vlastného kapitálu. Väčšinou už pri založení podniku vlastníci vložia skoro všetky svoje úspory a tak dodatočné vklady neprichádzajú do úvahy. Ak sa rozhodnú pre dodatočný vstup vlastníka, strácajú nezávislost' a samostatnost'.

Banky túto klientelu považujú za jednu najrizikovejších, pretože nemajú istotu, že klient bude dostatočne solventný. Aj napriek tomu finančné inštitúcie už niekol'ko rokov uvažujú o programoch pre malých a stredných podnikatel'ov, kde vidia najväčší problém 
$\mathrm{v}$ tom, že podnikatelia nie sú dostatočne pripravení podat' banke kvalitnú úverovú žiadost'. Na tomto princípe môže podnikatel' hned' na začiatku neuspiet'. Aby sa to nestalo, podnikatel' musí banke dokázat', že poskytnutí úver splatí. Banka posudzuje úver najmä z hl'adiska bonity klienta a úverového rizika.

Je zrejmé, že podnikatel' by mal vediet' reálne zhodnotit' situáciu na trhu a musí sa zorientovat' v produktoch, ktoré poskytujú konkrétne bankové inštitúcie. Súčasne pri posudzovaní žiadatel’a o úver je potrebné splńat' množstvo kritérií stanovených bankou.

Možné opatrenia:

1. Zvýšenie dostupnosti a použitel'nosti záruk pre podnikatelov, osobitne začinajúcich podnikatel'ov. Najtažším a najrizikovejším obdobím pre začínajúceho podnikatel'a je obdobie do jedného roka po začatí podnikania. V prípade, že sa udrží prvý rok, je pravdepodobné, že je firma života schopná a vydrží aj nasledujúce obdobia a bude schopná d'alšieho rozvoja. Možnost'ou zvýšenia dostupnosti môže byt' záruka úveru nehnutel'nost'ou, ktorou by začínajúci podnik mohol ručit' pri žiadosti o úver. Žiadatel'ovi by bol poskytnutý návratný úver s odkladom splátok. Ak sa firma udrží na trhu napríklad tri roky, záruka na nehnutel'nosti by mohla byt' odblokovaná a pôžička od banky alebo od štátu by sa zmenila na nenávratnú pôžičku. V tomto prípade by mal byt' celý tento proces kombinovaný v spolupráci so štátom vo forme tzv. „štátneho príspevku“, a zároveň upravený legislatívne. Inou možnost'ou je širšie uplatňovat' možnosti ručenia aj hnutel'ným majetkom, obstaraným z úveru; hnutel'ný majetok musí byt' ale bližšie špecifikovaný, pretože napr. dopravné zariadenia majú vyššiu mieru opotrebenia; úver by bol poskytnutý napr. na kratšiu dobu. Ďalšia možnost' je možnost' ručenia blankozmenkou.

2. Poskytnutie daňových úl'av (prázdnin) - napr. 1 - 2 roky.

3. Umožnenie širšieho a jednoduchšieho prístupu malých a stredných podnikatelov k podnikatel'ským úverom a podporným programov.

4. Hladanie možností poskytnutia výhodných finančných prostriedkov, resp. vytvorenia rizikového kapitálu pre malé a stredné podniky.

\section{Literatúra}

[1] BEDNÁROVÁ, L'.: Diplomová práca, Úverové možnosti malých a stredných podnikov, 2007

[2] Návrh štátnej strednodobej politiky podpory MSP. MINISTERSTVO HOSPODÁRSTVA [online]. [Citované 2007-03-29]. Dostupné na: http://www.ekonomy.gov.sk/pk/3756-2002-010/ma.doc. 